\title{
PEMAHAMAN PESERTA DIDIK TERHADAP PENDIDIKAN MANUSIA SECARA UTUH DAN KRISTIANI DI SMAK ST. AUGUSTINUS KEDIRI
}

\author{
Yohanes Ega Satriyo, Agustinus Supriyadi*) \\ STKIP Widya Yuwana \\ katekisyohanes@gmail.com \\ ${ }^{*}$ penulis korespondensi, atsywhw@widyayuwana.ac.id
}

\begin{abstract}
The whole human education includes: physical, spiritual, intellectual, sosial, moral and sexual aspects. Genrrally, the whole human education is seen as fostering physical and spiritual aspects. Gravissimum Educationis says that Christian education is also the whole human education in which the implementation is based on the spirit of gospel and Jesus Christ. Through Christian education, the students are provided various knowledges and preverences of life so that, they can participate to realize the public welfrare and the ultimate goal of salvation.

The development of a more and instant time has led to various aspects of life, including the process of education.The succes meaning of an education that should be emphasize the process, has sifted in meaning. The shifting meaning is evident from the efforts of the school or students who persue only academic values in a report of learning outcomes. In this regard, SMAK St. Augustinus Kediri, is one of Catholic educational institutions that must provide the whole and Christian human education. The issues that arise are: How is student's understanding on the wholeand Christian human education?How is the whole and Christian human education carried at SMAK St. Augustine Kediri? Based on the problems, the aim of this study is to describe students' understanding on the whole and Christian human at SMAK St. Augustinus Kediri and describe the implementation of thewhole and Christian human educationat SMAK St. Augustine Kediri.

Through qualitative research, interviews were conducted to 10 respondents of grade XII SMAK St. Augustine Kediri. The conclusion of the study are: first, students understand the meaning of the whole human education. Second, students understand the meaning of Christian education. Third, wholeand Christian human education has almost been implemented at SMAK St. Augustinus Kediri, but there are still some things that need to be improved.
\end{abstract}

Keywords: Students, Human Education, as a whole and Christianity 


\section{PENDAHULUAN}

Pendidikan memiliki makna yang sangat penting bagi kehidupan. Pendidikan juga memiliki pengaruh yang makin besar dalam kehidupan sosial, ekonomi dan politik. Pendidikan dalam arti sesungguhnya, bertujuan untuk mempersiapkan manusia-manusia yang berguna dan turut mengembangkan kesejahteraan masyarakat. Tujuan pendidikan, pertama-tama harus dipahami sebagai sebuah proses pendidikan yang berorientasi pada pembinaan pribadi manusia. Pembinaan pribadi manusia merupakan pembinaan yang mencakup seluruh aspek jasmani dan rohani. Melalui pembinaan pribadi manusia, siswa akan tumbuh menjadi manusia-manusia yang berguna yang dapat menunaikan tugas dan kewajibannya sesuai dengan profesi dan keahliannya masing-masing (GE 2\&3).

Lingkungan pendidikan dibedakan menjadi 3 (tiga), yaitu: lingkungan keluarga, lingkungan sekolah, dan lingkungan masyarakat (Ariana, 2017: 36). Proses pendidikan, pada dasarnya berlangsung di dalam keluarga dan dilanjutkan melalui pendidikan formal di sekolah. Pendidikan pertama-tama diberikan dalam keluarga melalui orangtua. Orangtua dengan segala keterbatasannya, memerlukan bantuan dari sekolah dan masyarakat untuk turut serta mendidik anak-anaknya (GE 3).

Gereja memiliki perhatian yang besar terhadap pendidikan, perhatian tersebut secara nyata nampak dalam wujud sekolah Katolik, mengingat betapa pentingnya pendidikan bagi masyarakat luas. Sekolah Katolik melaksanakan pendidikan berdasarkan kurikulum nasional. Sekolah Katolik sama halnya dengan sekolah-sekolah yang lainnya dalam hal melaksanakan pendidikan, hanya saja yang membuatnya berbeda adalah identitas kekatolikan. Identitas Katolik yang dimiliki oleh lembaga-lembaga pendidikan Katolik, terwujud dalam pelaksanaan pendidikan yang berhembuskan nafas Kristiani. Sekolah Katolik menjalankan setiap proses pendidikan dengan memandang peserta didik sebagai seorang pribadi yang harus menerima pendididikan secara lengkap serta utuh. Sekolah Katolik berkewajiban memberikan pendidikan demi kematangan pribadi manusia melalui semangat Kristus, dengan demikian terjadilah pendidikan manusia secara utuh (GE 8). Pelaksanakan pendidikan manusia secara utuh merupakan tugas dan tanggung jawab yang berat bagi Gereja dalam dunia pendidikan. Pelaksanaan pendidikan manusia secara utuh haruslah mencakup kematangan pribadi manusia, termasuk di dalamnya aspek iman melalui pendidikan Kristen. Kematangan pribadi manusia meliputi aspek: intelektual, sosial, moral, seksual, dan aspekaspek lainnya. Pendidikan Kristen hendak menghantarkan para peserta kepada kematangan pribadi manusia, agar semakin serupa dengan Kristus. Kristus merupakan sumber titik tolak dari setiap pendidikan Kristen, supaya siswa memiliki sikap totalitas penuh dalam menanggapi kehendak Allah. Totalitas 
tersebut seturut dengan yang Yesus lakukan yakni, setia sampai mati bahkan di kayu salib.

Sekolah Katolik mengalami berbagai kesulitan untuk melaksanaan pendidikan manusia secara utuh dan Kristiani. Pendidikan manusia secara utuh dan Kristiani yang seharusnya lebih berorientasi terhadap proses pendidikan yang utuh, dihadapkan dengan tuntutan akademik maupun perkembangan zaman yang semakin pragmatis dan instan. Kesuksesan dari pendidikan, kini cenderung hanya dilihat dari nilai-nilai akademis dalam sebuah laporan hasil belajar. Sebagai contoh, tradisi mencontek yang dilakukan oleh siswa-siswi pada saat ujian demi mendapatkan nilai yang bagus. Padahal nilai ujian sekolah dan ujian nasional dipakai sebagai salah satu persyaratan untuk mendaftar ke sekolah atau universitas ternama. Hal tersebut juga diungkapkan oleh Judo, dkk:

"Banyak lembaga pendidikan Katolik dewasa ini dihadapkan pada dilema pelik untuk menentukan skala prioritas antara menguatkan identitas diri atau lebih mengedepankan tuntutan akademik... atas desakan orangtua peserta didik, yayasan dan para guru diarahkan untuk lebih fokus pada lulusan UN karena itu dianggap menjadi tolok ukur kepuasan orangtua peserta didik." (Judo, dkk. 2017:3)

Tujuan pendidikan sebagaimana dicanangkan oleh Gereja dan negara, akan sulit diwujudkan, mengingat realitas dunia yang semakin pragmatis dan instan ini. Pendidikan yang bertujuan untuk membentuk manusia secara utuh, harus dilihat sebagai pendidikan yang menyentuh aspek intelektual sekaligus spiritual. Pendidikan yang menafikan salah satu aspek dan lebih menonjolkan aspek yang lain, tentu bukanlah tujuan dari pendidikan yang sebenarnya.

Berdasarkan uraian di atas, ada beberapa pertanyaan yang perlu diajukan antara lain adalah: Apakah SMAK St. Augustinus-Kediri yang adalah sekolah Katolik, sungguh menyadari tugasnya sebagai sekolah Katolik? Apakah sekolahsekolah Katolik, khususnya di SMAK St. Augustinus-Kediri telah melaksanakan pendidikan manusia secara utuh dan Kristiani? Apakah peserta didik di SMAK St. Augustius-Kediri mengalami perkembangan pada aspek religius Kristen dan kematangan pribadi?

\section{PENDIDIKAN MANUSIA SECARA UTUH DAN KRISTIANI}

\subsection{Pengertian Pendidikan}

Pendidikan selalu disebut-sebut sebagai salah satu unsur penting untuk membangun sebuah negara. Pendidikan diharapkan mampu menunjang terwujudnya kesejahteraan masyarakat baik di bidang politik, sosial, ekonomi dan lain sebagainya. Manusia merupakan bagian dari masyarakat, maka setiap pribadi 
dituntut memiliki kompetensi dalam aneka bidang kehidupan untuk menunjang kesejahteraan umum.

Mujahir dalam Kadir (2012: 59) mengatakan bahwa secara etimologi, pendidikan berasal dari kata Yunani, paedagogy yang berarti ilmu atau seni dalam mendidik anak. Paedagogy diandaikan seperti seorang anak yang pulang pergi ke sekolah dihantar oleh seorang pelayan. Pelayan yang menghantar dan menjemput pulang dinamakan paedagogos. Ilmu mendidik senantiasa dikembangkan dan dipelajari, kemudian digunakan sebagai cara guru melatih dan mengembangkan potensi anak dalam proses pendidikan. Pendidikan dalam bahasa Latin, diistilahkan sebagai educare yang artinya mengeluarkan sesuatu yang berada di dalam. Pendidikan diistilahkan sebagai to educate dalam bahasa Inggris, yang artinya memperbaiki moral dan melatih intelektual. Singkatnya, pendidikan merupakan sebuah proses ataupun kegiatan membimbing, menuntun, dan mengembangkan aspek-aspek yang terdapat pada manusia.

Bambang Sudibjo dalam Ali (2009: i) mengungkapkan bahwa pendidikan merupakan hak asasi manusia dan kebutuhan pembangunan kesejahteraan umum. Ungkapan tersebut berbanding lurus dengan amanat Undang Undang Dasar Negara Republik Indonesia 1945 yang telah diamandemen. Pasal 31 ayat 1 UUD 1945 yang telah diamandemen mengamanatkan: "Setiap warga negara berhak mendapat pendidikan.”

Gereja Katolik menyerukan pendapat yang senada dengan Bambang Sudibjo, melalui Konsili Vatikan II bahwa:

"Semua orang dari suku, kondisi, atau usia manapun, berdasarkan martabat mereka selaku pribadi, mempunyai hak yang tak dapat diganggu gugat atas pendidikan. Pendidikan tersebut haruslah sesuai dengan tujuan maupun sikap perangai mereka, mengindahkan perbedaan jenis, serasi dengan tradisi-tradisi kebudayaan serta para leluhur, sekaligus juga terbuka bagi persekutuan persaudaraan dengan bangsa-bangsa lain, untuk menumbuhkan kesatuan dan damai yang sejati di dunia.” (GE 1)

\subsection{Manusia secara Utuh}

Manusia secara utuh dipandang sebagai kesatuan aspek jasmani dan rohani. Gereja memandang bahwa terdapat aspek-aspek tertentu dalam diri manusia. Gereja menyebutkan bahwa aspek-aspek yang terdapat pada manusia adalah:

"Pribadi manusia harus diselamatkan, dan masyarakatnya diperbaharui. Maka, manusia dipandang dalam kesatuan dan keutuhannya, beserta jiwa maupun raganya, dengan hati serta nuraninya, dengan budi dan kehendaknya merupakan poros seluruh uraian kami.” (GS 3) 
Peneliti memahami bahwa yang dimaksud dengan manusia secara utuh, haruslah dipandang sebagai suatu keutuhan jiwa dan raga manusia. Manusia memiliki sifat hakiki yang khas dan tidak dimiliki oleh makhluk hidup lainnya. Sifat hakiki manusia mencakup aspek intekektual, sosial, moral, dan aspek seksual serta aspek-aspek lainnya (GE 1). Pembahasan selanjutnya akan diberikan penjelasan untuk memperdalam pemahaman tentang aspek: jasmani, rohani, intelektual, sosial, moral, dan seksual.

\subsubsection{Aspek Jasmani}

Pemerintah Indonesia memiliki perhatian terhadap pendidikan jasmani bagi anak-anak, mulai dari PAUD sampai dengan SMA. Perhatian pemerintah terwujud dalam undang-undang mengenai pelaksanaan pendidikan jasmani, olahraga dan kesehatan (PENJAS ORKES). UU RI No.2 Tahun 1989 tentang Sistem Pendidikan Nasional, mengatakan bahwa: pendidikan jasmani menuju kepada keselarasan antara tumbuhnya badan dan perkembangan jiwa dan merupakan suatu usaha untuk membuat bangsa Indonesia menjadi bangsa yang sehat dan kuat lahir batin, diberikan kepada segala jenis sekolah (UU RI No.2 Tahun 1989 pasal 9).

Mustafah mengatakan hal yang senada dengan peraturan pemerintah tentang pendidikan jasmani, bahwa: “pendidikan jasmani tidak hanya sebatas kesadaran masyarakat mengenai pentingnya berolahraga. Pendidikan jasmani juga harus menumbuhkan kesadaran masyarakat untuk mengatur pola hidup yang sehat dengan mengkonsumsi makanan bergizi dan istirahat yang cukup.” (Mustafah, 2012: 8)

Syarifudin Santoso (2009:3) melengkapi dari apa yang disampaikan Mustafah. Syarifudin mengatakan, pendidikan jasmani adalah suatu proses melalui aktivitas jasmani, yang dirancang dan disusun secara sistematik untuk merangsang pertumbuhan dan perkembangan, meningkatkan kemampuan dan keterampilan jasmani, kecerdasan dan pembentukan watak, serta nilai dan positif bagi setiap warga negara dalam rangka mencapai tujuan pendidikan. Pendidikan jasmani merupakan kegiatan olahraga dan menjaga pola hidup sehat melalui kebiasaan mengatur pola makan dan waktu istirahat untuk meningkatkan kebugaran tubuh.

\subsubsection{Aspek Rohani}

Aspek rohani memiliki peranan yang penting bagi manusia, pertama-tama karena manusia sendiri merupakan makhluk rohani. Manusia mampu mendekatkan diri kepada yang Ilahi melalui sisi rohaninya. Pemerintah memandang bahwa pendidikan rohani sangatlah diperlukan dalam dunia pendidikan, oleh karena itu melalui pasal 31 ayat 3 UUD 1945, dikatakan: 
"Pemerintah supaya mengusahakan dan menyelenggarakan suatu sistem pendidikan nasional yang meningkatkan keimanan dan ketaqwaan kepada Tuhan Yang Maha Esa serta akhlak mulia dalam rangka mencerdaskan kehidupan bangsa.”

Gereja juga memberikan perhatiannya yang besar terhadap pendidikan aspek rohani. Perhatian Gereja terhadap pendidikan rohani terlihat dari pendahuluan dokumen Konsili Vatikan II mengenai Pendidikan Katolik, yang mengatakan bahwa:

“Adapun melaksanakan perintah pendiri Ilahi, yakni mewartakan misteri keselamatan kepada semua orang yang membarui segalanya dalam Kristus, Bunda Gereja yang kudus, wajib memelihara perihidup manusia seutuhnya, juga di dunia ini, sejauh berhubungan dengan panggilan surgawinya.” (Pendahuluan GE).

Gereja menghendaki supaya manusia dibimbing dan dibina sisi rohaninya supaya manusia mencapai tujuan terakhirnya yaitu keselamatan.

\subsubsection{Aspek Intelektual}

Manusia memiliki tingkat kecerdasan yang berbeda antara satu dengan yang lainnya. Kecerdasan manusia bisa diasah dan dikembangkan melalui berbagai macam cara, salah satunya melalui pendidikan (kegiatan belajar mengajar). Ali, (2009: 35) mengatakan bahwa mencerdaskan manusia melalui pendidikan mampu menghantarkan manusia untuk mencapai kesuksesan, keberhasilan serta mewujudkan kebahagiaan di dalam kehidupan. Mustafah, (2012: 8) mengatakan hal yang sama, sebagaimana disampaikan oleh Ali, bahwa pengetahuan yang mendalam menghantar manusia pada kecerdasan dan keterampilan yang sangat bermanfaat untuk modal bekerja pada berbagai bidang. Kecerdasan dan keterampilan mampu menghantarkan manusia untuk mencapai kesejahteraan ekonomi, sehingga mampu memenuhi kebutuhan dasarnya sebagai manusia, seperti rumah, makanan, kendaraan, rasa aman, cinta, diakui, aktualisasi diri dan seterusnya. Gereja juga menyinggung tentang intelektual manusia. Dokumen Konsili Vatikan II mengatakan bahwa: “Oleh akal budinya (intelektualitas), manusia mendengarkan suara Allah yang mengajaknya untuk mencintai serta melakukan yang baik dan mengelakkan yang jahat (GS 16)”.

\subsubsection{Aspek Sosial}

Manusia mampu mengembangkan berbagai macam potensi yang ada pada dirinya bila manusia hidup dan belajar dari orang lain (Suratman, dkk. 2010: 135). Hanifah menambahkan pendapat Sutarman, bahwa: pendidikan sosial perlu diberikan di sekolah. Pendidikan sosial diberikan supaya siswa mampu 
bersosialisasi dan menyesuaikan diri dengan lingkungannya, serta meningkatkan kesadaran terhadap permasalahan yang ada khususnya permasalahanpermasalahan kemanusiaan (Hanifah, 2014: 149). Gereja melalui Konsili Vatikan II, meninggung tentang aspek sosial dengan mengatakan:

"Pribadi manusia membutuhkan kehidupan sosial. Ini tidak berarti pelengkap bagi dirinya tetapi suatu tuntutan kodratnya. Melalui pertemuan dengan orang lain, melalui pelayanan timbal balik, dan melalui dialog dengan saudara dan saudarinya, manusia mengembangkan bakat-bakatnya dan dapat menjalankan panggilannya.” (GS 25\&1).

Peneliti memahami bahwa perjumpaan manusia dengan manusia yang lain amatlah penting. Manusia melakukan proses belajar dan saling melengkapi satu dengan yang lainnya, melalui kegiatan timbal-balik antar sesama manusia. Singkatnya, manusia memang membutuhkan dan dibutuhkan oleh orang lain, untuk membuat manusia semakin manusiawi.

\subsubsection{Aspek Moral}

Moral dipahami sebagai sesuatu yang berkaitan dengan hal baik dan buruk. Manusia perlu mempelajari dan meningkatkan aspek moral pada dirinya, sebab ajaran tentang baik-buruk yang dipahami oleh seseorang bisa berbeda-beda. Sebagai contoh, anak yang tumbuh di lingkungan pencuri, menganggap bahwa mencuri adalah perbuatan yang wajar. Anak yang tumbuh dan berkembang di lingkungan pencuri, tidak bisa disalahkan jika beranggapan bahwa mencuri adalah sah. Anak-anak banyak belajar dari kebiasaan-kebiasan di lingkungannya, sehingga tidak bisa dipungkiri jika terdapat orang-orang yang memiliki penilaian moral yang berbeda. Sekolah memiliki peran yang besar untuk memberikan ajaran-ajaran moral yang tepat, mengenai tindakan yang baik dan buruk demi terwujudnya kebaikan bersama (Bdk. Sagala, 2013: 222).

\subsubsection{Aspek Seksual}

Seksualitas cenderung dipandang sebagai sesuatu yang negatif (Abineno, 2002: 1). Media massa kerap kali membahas tentang pemerkosaan, pelacuran, dan lain-lain.

Seksualitas mengalami pergeseran nilai yang disebabkan oleh kurangnya pengetahuan mengenai arti dan makna seksualitas. Pengetahuan tentang seksualitas yang minim mengakibatkan pembahasan mengenai seks (bahkan dalam konteks pendidikan) dianggap sebagai hal tabu untuk diperbincangkan. Pendidikan seksual dibedakan menjadi dua, yaitu Sex Instruction, dan Sex Education. Sex Instruction adalah penerangan mengenai seks dalam hal perubahan anatomi dan perubahan organ reproduksi dalam tubuh manusia, sehubungan 
dengan hormon reproduksi. Sex Education menyangkut perihal etika, moral, fisiologi, ekonomi, dan pengetahuan lainnya agar seseorang memahami dirinya merupakan individu seksual dan mengadakan hubungan intrerpersonal dengan baik (Mujahir, 2007:96). Pendidikan mengenai seksualitas, sejatinya diperlukan terutama bagi anak-anak yang mulai tumbuh dan berkembang.

"Dengan memanfaatka kemajuan ilmu pengetahuan psikologi, pedadogi, dan didaktik, perlulah anak-anak dan kaum remaja dibantu untuk menumbuhkan secara laras serasi... Serta pendidikan seksualitas yang bijaksana sesuai dengan perkembangan usianya."(GE1).

Pendidikan seksual diberikan secara bertahap sesuai dengan perkembangan dan usia anak, dengan demikian anak-anak akan terhindar dari seks bebas dan berbagai bentuk penyimpangan seksual lainnya.

\subsection{Pendidikan Kristiani}

Pendidikan Kristen mengupayakan pengolahan potensi manusia secara menyeluruh. Keseluruhan potensi pada diri manusia, secara umum dipandang dari segi jasmani dan rohani. Pendidikan Katolik diberikan untuk menunjang kesejahteraan hidup secara pribadi dan masyarakat (GE 1). Pendidikan Katolik juga hendak mewujudkan supaya manusia mengalami perkembangan rohani dengan memuliakan Allah. Aspek rohani manusia yang berkembang, ditandai dari kedewasaan manusia secara penuh, yang sesuai dengan kepenuhan Kristus (GE 2).

Pendidikan Katolik merupakan pendidikan manusia secara menyeluruh. Keseluruhan pendidikan manusia, mencakup bagian jasmani dan rohani. Ciri khas pendidikan Katolik terletak pada pendidikan rohani manusia yang didasarkan pada Yesus Kristus dan Injil. Pengertian mengenai ciri khas pendidikan Katolik, akan diberikan melalui uraian tentang: integrasi iman dan kebudayaan, integrasi iman dan hidup, pembinaan iman Kristen, penanggungjawab pendidikan Katolik dan sekolah Katolik sebagai pusat komunitas Katolik yang mendidik.

\subsubsection{Integritas Iman dan Kebudayaan}

Integrasi iman dan kebudayaan dalam pendidikan Katolik, mengisyaratkan perpaduan antara iman dan pengetahuan. Iman dan pengetahuan hendak diintegrasikan dengan mengajarkan kepada peserta didik mengenai pengetahuan manusiawi melalui mata pelajaran, kemudian meneranginya dengan cahaya Injil (GE 8). KWI Majelis Nasional Pendidikan Katolik, menyinggung perihal integritas iman dan kebudayaan, bahwa: 
“Tugas pendidikan sekolah Katolik begitu luas, maka guru berada dalam kedudukan utama dalam membimbing murid, memperdalam imannya dan memperkaya serta menerangi pengetahuan manusiawinya dengan bahan-bahan iman. Meskipun banyak kesempatan dalam pengajaran dimana para murid dapat dirangsang oleh pandangan iman, namun pendidikan Kristen mengetahui sumbangan sah yang dapat diberikan oleh mata pelajaran akademik untuk pembangunan seorang Kristen yang matang. Guru dapat membentuk pikiran dan hati para muridnya dan membimbing mereka mengembangkan keterlibatan kepada Yesus Kristus secara utuh, dengan seluruh kepribadian mereka yang diperkaya oleh kebudayaan manusia.” (KWI Majelis Nasional Pendidikan Katolik, 2013: 39).

Peneliti dapat memahami bahwa dalam pengintegrasian iman dan kebudayaan, peserta didik dibantu supaya menjadi orang-orang yang matang secara pengetahuan dan juga secara iman. Dengan demikian, siswa akan menjadi orang-orang yang beriman sekaligus juga menjadi orang yang kritis (tidak radikal).

\subsubsection{Integritas Iman dan Hidup}

Integrasi iman dan hidup dalam pendidikan Katolik, merupakan upaya menumbuhkan keutamaan-keutamaan yang khas sebagai seorang Katolik dalam diri peserta didik melalui pengajaran. Tujuan pokok pengajaran adalah mempersatukan nilai-nilai obyektif, dan bila dijadikan untuk tujuan kerasulan, pengajaran tidak berhenti pada integrasi iman dan kebudayaan sebagaimana disebutkan di atas. Integrasi iman dan hidup dimaksudkan untuk menghantar peserta didik menuju integrasi iman dan hidup pribadinya, kemudian iman yang dihidupinya tersebut dinyatakan melalui tindakan sebagai kesaksian kepada sesama (GE 2).

Integrasi iman dan hidup, semakin nyata melalui tindakan hidup seharihari sebagai bentuk kesaksian kepada sesamanya. Sekolah Katolik memegang peranan yang penting untuk mengintegrasikan iman siswa melalui tindakan nyata dalam hidup khususya di sekolah, sebagaimana dinyatan oleh "KWI Majelis Nasional Pendidikan Katolik”, bahwa:

"Sekolah Katolik agar mengajar murid-muridnya melihat dalam suara alam semesta Pencipta yang diungkapkannya, dan dalam menaklukkan ilmu mengenal Allah dan manusia dengan lebih baik. Dalam kehidupan sekolah sehari-hari hendaknya murid belajar tahu bahwa ia dipanggil sebagai saksi hidup atas cinta Allah kepada manusia melalui caranya bertindak, dan bahwa ia merupakan bagian dari sejarah 
keselamatan yang menuju kepada Kristus, penebus dunia.” (KWI Majelis Nasional Pendidikan Katolik, 2013: 46)

\subsubsection{Pembinaan Iman Kristen}

Pembinaan iman Kristen, merupakan hak yang dimiliki oleh setiap anggota Gereja, oleh karena anugerah pembaptisannya. Pembinaan iman Kristen secara khusus di sekolah Katolik, hendak mendidik para murid agar semakin menyadari misteri penyelamatan dan menyadari anugerah iman supaya manusia mampu beribadah kepada Allah. Melalui pembinaan iman Kristen, peserta didik semakin dihantarkan kepada kedewasaan penuh, serta tingkat pertumbuhan yang sesuai dengan kepenuhan Kristus. Selain itu, pendidikan Katolik juga dimaksudkan untuk melatih peserta didik supaya mampu memberikan kesaksian melalui hidupnya (GE 2).

Dalam upaya pembinaan iman di sekolah, dilakukan berbagai macan kegiatan yang menunjang perkembangan iman peserta didik. Gereja melalui Konsili Vatikan II, secara jelas mengungkapkan bahwa:

"Dalam menunaikan tugasnya di bidang pendidikan, Gereja memperhatikan, mendukung dan mengusahakan upaya-upaya yang khas. Di antaranya yang utama adalah pendidikan katekese, yang menyinari dan meneguhkan iman, menyediakan santapan bagi hidup menurut semangat Kristus, yang menghantar pada peran serta yang aktif dan sadar dalam misteri liturgi dan yang merangsang kegiatan kerasulan.” (GE 4).

\subsubsection{Penanggungjawab Pendidikan Kristen}

Orangtua memiliki tanggung jawab untuk memberikan pendidikan bagi anak-anaknya. Undang-undang Republik Indonesia nomor 20 tahun 2003 pasal 7 ayat 2 mengatakan bahwa: Orangtua dari anak usia wajib belajar, berkewajiban memberikan pendidikan dasar kepada anaknya. Sejalan dengan apa yang tertuliskan pada Undang-undang nomor 20 tahun 2003 pasal 7 ayat 2, Gereja juga memandang bahwa penanggungjawab pendidikan Kristen pertama-tama terletak pada orangtua (Supriyadi, 2019: 30). Orangtua berkewajiban untuk menciptakan lingkungan keluarga, yang diliputi semangat bakti kepada Allah dan kasih sayang terhadap sesama. Dengan demikian, dapat dipahami bahwa orangtua adalah pendidik utama dan utama. Orangtua dengan segala keterbatasannya, memercayakan pendidikan anaknya kepada masyarakat (sekolah) untuk membantu memberikan pendidikan bagi anak-anaknya (Dewantara, 2018: 44). 


\subsubsection{Sekolah Katolik sebagai Pusat Komunitas Iman yang Mendidik}

Sekolah Katolik merupakan sarana pembentukan manusia secara utuh yang membantu orangtua dalam mendidik putra-putrinya. Sekolah Katolik dipahami sebagai komunitas iman yang mendidik dengan menciptakan lingkungan hidup bersama di sekolah, dijiwai oleh semangat Injil kebebasan dan cinta kasih, dan mengembangkan kepribadian kaum muda (GE 8). Buku dari Papo yang berjudul "Hidup Beriman dalam Lingkup Sekolah" ini, senada dengan Gravissimum Educationis, bahwa:

"Sekolah dipahami tidak hanya sebagai pendidikan formal dengan kurikulumnya, tetapi juga segala unsur yang meliputi lembaga itu. Unsur-unsur itu adalah: struktur, peluang kecerahan masa depan, kondisi lingkungan sekolah yang menyeluruh, kondisi lingkungan hidup anak sekolah, wawasan yang berorientasi pada hidup dan mau terlibat dalam masyarakat.” (Papo, 1990: 17)

Memahami bahwa sekolah Katolik sebagai komunitas iman yang mendidik, berarti membutuhkan partisipasi dari setiap pribadi yang ada di sekolah tersebut. Guru, murid, komite, dan semua pihak yang terkait, berpartisipasi untuk mewujudkan suasana lingkungan sekolah yang nyaman dan disemangati oleh cinta kasih. Suasana lingkungan sekolah uang menyenangkan akan menunjang proses pendidikan agar semakin kondusif.

\section{PEMAHAMAN SISWA MENGENAI PENDIDIKAN MANUSIA SECARA UTUH DAN KRISTIANI SERTA PELAKSANAANNYA DI SMAK ST. AUGUSTINUS KEDIRI}

Untuk mendapatkan deskripsi mengenai pemahaman siswa tentang pendidikan manusia secara utuh dan Kristiani serta pelaksanaannya di SMAK St. Augustinus Kediri, maka perlu dilakukan wawancara atas 10 responden dari siswa kelas XII SMAK St. Augustinus Kediri, pada tanggal 23-24 November 2018. Penggunaaan instrumen penelitian bertujuan agar wawancara berjalan dengan sistematis dan terukur. Instrumen penelitian yang disusun, dilandaskan pada 3 pokok pembahasan kemudian diuraikan menjadi 14 pertanyaan untuk diajukan kepada responden, berikut akan diuraikan hasil penelitian di bawah ini:

\subsection{Pemahaman Siswa Mengenai Pendidikan Manusia Secara Utuh}

Siswa dapat memahami tentang arti pendidikan. Data penelitian menunjukkan bahwa dari $100 \%$ responden, $80 \%$ responden memahami pendidikan sebagai upaya pengolahan aspek intelektual. Dari 80\% responden yang memahami pendidikan sebagai upaya pengolahan aspek intelektual, sebanyak 50\% responden mengkaitkan pendidikan dengan tujuannya yaitu untuk 
mewujudkan masadepan yang cerah. Kemudian, 50\% responden dari responden yang mengkaitkan pendidikan dengan tujuannya yaitu untuk mewujudkan masadepan yang cerah mengatakan bahwa pendidikan bertujuan agar seseorang bisa menjadi lebih baik. Menyusul kemudian, 30\% responden yang memahami pendidikan sebagai upaya pengolahan aspek intelektual, juga memahami tentang pendidikan sebagai pengolahan aspek jasmani dan rohani. Selain jawabanjawaban tersebut, terdapat $10 \%$ responden yang menjawab bahwa pendidikan berkaitan dengan: pendidikan moral, sosial, kepribadian, dan kematangan emosional.

Berdasarkan pertanyaan tentang arti pendidikan jasmani, data penelitian menunjukkan bahwa sebanyak 70\% responden menyatakan pendidikan jasmani sebagai pendidikan olahraga sebagaimana dilakukan di sekolah. Kemudian, sebanyak 60\% responden diantaranya menyatakan bahwa pendidikan jasmani juga merupakan pendidikan tentang kesehatan fisik. Selanjutnya, 30\% responden juga menyatakan bahwa pendidikan jasmani merupakan pendidikan tentang pola hidup sehat. $10 \%$ responden juga menyatakan bahwa pendidikan jasmani merupakan pendidikan tentang perkembangan fisik, dan 10\% responen juga menjawab bahwa pendidikan yang mengolah sisi motorik.

Berkaitan dengan pemahaman siswa tentang pendidikan rohani, dapat dikatakan bahwa sebagian besar dari responden sudah memahami tentang pendidikan rohani. Data penelitian menunjukkan bahwa sebanyak 90\% responden mengkaitkan pendidikan rohani dengan tujuannya yaitu, untuk mengembangkan iman dan menjalin relasi dengan Allah. Kemudian terdapat 50\% responden diantaranya, memahami pendidikan rohani sebagai bentuk-bentuk kegiatan pastoral di sekolah. Terdapat $10 \%$ responden yang juga memberikan jawaban kurang sesuai dengan teori yang ada. Siswa tersebut mengatakan bahwa pendidikan rohani merupakan pendidikan untuk meneguhkan orang supaya tidak mudah tersinggung.

Berkaitan dengan pemahaman siswa mengenai pendidikan intelektual, dapat dikatakan bahwa seluruh responden (100\%) dapat memahami arti pendidikan intelektual. Data penelitian menunjukkan bahwa, sebanyak 50\% responden mengkaitkan pendidikan intelektual dengan proses belajar-mengajar antara guru dengan murid. Selanjutnya, terdapat 50\% responden menjawab bahwa pendidikan intelektual berhubungan dengan upaya mengembangkan kecerdasan dan pengetahuan. Menyusul kemudian, terdapat $40 \%$ responden diantaranya juga menjelaskan bahwa pendidikan intelektual berhubungan dengan upaya mempelajari sebuah disiplin ilmu tertentu.

Berkenaan dengan pemahaman siswa mengenai pendidikan sosial, sebanyak 90\% responden menyatakan bahwa pendidikan sosial merupakan pendidikan yang menumbuhkan jiwa sosial. Selanjutnya, $10 \%$ responden 
mengatakan bahwa pendidikan sosial merupakan pendidikan yang menumbuhkan toleransi. $10 \%$ responden juga mengatakan bahwa pendidikan sosial merupakan pendidikan untuk peningkatan kualitas pribadi. Dengan demikian dapat dikatakan bahwa $100 \%$ responden dapat memahami arti pendididkan sosial.

Berkaitan dengan pemahaman siswa mengenai pendidikan moral, dapat dikatakan bahwa semua responden (100\%) memahami arti pendidikan moral. Data penelitian menunjukkan bahwa sebagian besar 70\% responden mengatakan bahwa pendidikan moral merupakan pendidikan tentang baik dan buruk. Sebanyak 30\% responden menyatakan bahwa pendidikan moral adalah pendidikan tentang tingkah laku seseorang. Terdapat 10\% responden mengkaitkan pendidikan moral dengan upaya menumbuhkan kesadaran dalam bertindak, dan $10 \%$ responden mengaitkan antara pendidikan moral dengan harga diri seseorang.

Berkaitan dengan pemahaman siswa mengenai pendidikan seksual, dapat diketahui bahwa responden belum memiliki pemahaman yang mendalam mengenai arti pendidikan seksual. Data penelitian menunjukkan bahwa sebanyak 90\% responden masih memaham arti pendidikan seksual yang berkaitan dengan upaya-upaya menjalin relasi yang sehat antar lawan jenis dan cara-cara untuk tidak terjerumus pada pergaulan bebas. Pemahaman seksualitas sebagai suatu hubungan yang memilki nilai luhur belum terungkap dari jawaban responden. Bahkan, terdapat $10 \%$ responden memberikan jawaban yang tidak sesuai dengan teori yang ada, sebab baginya pendidikan seksual tidak perlu diberikan di sekolah.

\subsection{Pemahaman Siswa Mengenai Pendidikan Kristen}

Berkaitan dengan pemahaman siswa mengenai arti pendidikan Katolik, dapat dikatakan bahwa sebagian besar responden belum memahami arti pendidikan Katolik. Data penelitian menunjukkan bahwa terdapat 60\% responden yang memiliki pemahaman bahwa pendidikan Katolik hanya mengolah dan mengembangkan sisi keagamaan saja, sedangkan 40\% responden mampu memahami pengertian dari pendidikan Katolik. Pendidikan Katolik tidak melulu menekankan keagamaan saja, tetapi juga memberikan pendidikan secara umum (ilmu pengetahuan) dan mengutamakan pendidikan manusia secara utuh.

Berkaitan dengan pemahaman siswa mengenai pembinaan iman Katolik, dapat dikatakan bahwa seluruh responden (100\%) memahami tentang pembinaan iman Katolik. Data penelitian menunjukkan bahwa sebagian besar 80\% responden mengkaitkan pembinaan iman Katolik dengan pastoral yang ada di sekolah. Sebanyak 30\% responden mengatakan bahwa pembinaan iman Katolik merupakan upaya untuk meneladan pribadi Yesus Kristus. Kemudian 20\% responden mengatakan bahwa pembinaan iman Katolik merupakan pembinaan untuk hidup menggereja. 
Berdasarkan data penelitian mengenai pemahaman siswa tentang keselarasan antara iman dan perbuatan, semua responden (100\%) mengatakan bahwa pendidikan Katolik harus mengajarkan keselarasan antara iman dan perbuatan. Dengan demikian dapat dikatakan bahwa siswa memahami bahwa sekolah Katolik harus mengajarkan keselarasan antara iman dan perbuatan.

Berdasarkan data penelitian mengenai pemahaman siswa tentang komunitas katolik sebagai komunitas yang mendidik, semua responden (100\%) setuju bilamana pendidikan Katolik harus menjadi sebuah sarana komunitas yang mendidik. Dengan demikian dapat dikatakan bahwa siswa memahami bahwa sekolah Katolik harus menjadi sebuah komunitas iman yang saling mendidik.

\subsection{Pelaksanaan Pendidikan Manusia secara Utuh dan Pendidikan Kristiani di SMAK St. Augustinus Kediri \\ Berkaitan dengan pelaksanaan pendidikan manusia secara utuh di SMAK} St. Augustinus Kediri, sebanyak 90\% responden mengatakan bahwa pendidikan manusia secara utuh sudah dilaksanakan dengan baik di SMAK St. Augustinus Kediri dan terdapat $10 \%$ responden mengatakan bahwa hampir seluruhnya sudah dilaksanakan, hanya saja pendidikan sosial masih perlu ditingkatkan lagi.

Berkaitan dengan pelaksanaan pendidikan Kristiani di SMAK St. Augustinus Kediri, data penelitian menunjukkan bahwa 100\% responden mengatakan bahwa pendidikan tersebut sudah diberikan oleh pihak SMAK St. Augustinus Kediri. Sebanyak 90\% responden mengatakan bahwa partisipasi siswa untuk mengikuti segala bentuk kegiatan pembinaan iman masih sangat rendah. Dari $90 \%$ responden yang mengatakan hal tersebut, di antaranya terdapat $40 \%$ responden yang mengatakan lebih spesifik, yaitu minimnya keterlibatan tersebut justru dari siswa yang beragama Katolik. Terdapat 30\% responden yang justru mengatakan bahwa terdapat partisipasi dari siswa non-Katolik. Dari 30\% responden yang mengatakan terlibatnya siswa non-Katolik, terdapat $10 \%$ responden mengatakan bahwa keterlibatan dari siswa non-Katolik dimaksudkan untuk menghindari pelajaran. Dari uraian di atas dapat dipahami bahwa pihak SMAK St. Augustinus Kediri sudah memberikan pendidikan manusia secara Kristiani, namun proses pelaksanaannya belum berjalan dengan maksimal bahkan terdapat indikasi bahwa terjadi penyalahgunaan kegiatan pendidikan iman, sebagai alasan untuk menghindari jam pelajaran.

Berkaitan dengan harapan siswa terhadap SMAK St. Augustinus Kediri tentang peaksanaan pendidikan manusia secara utuh dan Kristiani, sebanyak 40\% responden mengharapkan supaya pembinaan iman dikemas dengan baik sehingga keterlibatan siswa meningkat. 30\% responden mengatakan bahwa guru harus lebih tegas kepada peserta didik. 30\% responden mengharapkan supaya keterlibatan 
peserta didik harus ditingkatkan. 20\% responden mengatakan bahwa kualitas pendidikan manusia secara utuh dan Kristiani perlu untuk semakin dikembangkan.

\section{KESIMPULAN}

Data penelitian telah diolah dan menghasilkan deskripsi mengenai pemahaman siswa tentang pendidikan manusia secara utuh dan Kristiani serta pelaksanaannya di SMAK St. Augustinus Kediri. Peneliti mencoba untuk menyimpulkan hasil penelitian dan didapatkan 3 kesimpulan pokok, yaitu:

Pertama, siswa memahami arti pendidikan manusia secara utuh. Data penelitian menunjukkan bahwa siswa mampu memberikan penjelasan mengenai pendidikan manusia secara utuh. Siswa menyebutkan aspek-aspek pendidikan manusia secara utuh, yang mencakup aspek: jasmani, rohani, intelektual, sosial, moral dan seksual. Namun, data penelitian juga menunjukkan bahwa terdapat siswa yang belum paham secara mendalam mengenai pendidikan seksual. Pemahaman pendidikan seksual yang kurang mendalam sebagaimana diungkapkan siswa, hanya menjangkau hal-hal yang berkaitan dengan pencegahan pergaulan bebas; cara menjalin relasi yang sehat antara lawan jenis dan pengertian seksual secara positif dan negatif. Pendidikan seksual yang mengarah kepada halhal luhur belum muncul pada jawaban yang ada.

Kedua, siswa memahami tentang pendidikan manusia secara Kristiani. Data penelitian menunjukkan bahwa siswa mampu menjelaskan tentang pembinaan iman Katolik, sekolah Katolik harus mengajarkan keselarasan antara iman dan perbuatan, sekolah Katolik sebagai komunitas iman yang mendidik, meskipun demikian terdapat pemahaman yang kurang tepat mengenai arti pendidikan Katolik. Data penelitian menunjukkan bahwa sebagian besar pemahaman siswa mengenai pendidikan Katolik, hanya terbatas pada pendidikan yang menekankan sisi keagamaan saja, sedangkan dalam arti yang sesungguhnya, pendidikan Katolik tidak hanya melulu memperdalam sisi keagamaan, melainkan juga memberikan pendidikan manusia yang seutuhnya pula.

Ketiga, proses pelaksanaan pendidikan manusia secara utuh dan Kristiani yang dilakukan di SMAK St. Augustinus Kediri, hampir semuanya sudah dijalankan oleh pihak SMAK St. Augustinus Kediri, namun dalam proses pelaksanaannya masih belum berjalan dengan baik. SMAK St. Augustinus Kediri perlu meningkatkan pendidikan sosial dan kualitas pembinaan iman. Pembinaan iman yang berkualitas, dimaksudkan untuk meningkatkan keterlibatan siswa untuk mengikuti setiap kegiatan rohani. 


\section{DAFTAR PUSTAKA}

., 1973, Alkitab Deuterokanonika, Jakarta, LAI.

., 1983, Dokumen Konsili Vatikan II (Hardawiryana, R., Penerjemah), Jakarta, Obor.

., 2016, Kitab Hukum Kanonik, Jakarta, KWI.

., 1993, Pedoman Pastoral Sekolah di Keuskupan Malang, Malang, Dioma ., 1989, Undang-Undang RI No. 2 Tahun 1989 tentang Sistem Pendidikan

Nasional, Jakarta, CV. Kloang Kelede Jaya

Abineno, J. L. C. H., 2002, Seksualitas dan Pendidikan, Jakarta, BPK Gunung Mulia

Ali, Mohammad., 2009, Pendidikan untuk Pembangunan Nasional, Jakarta, Grasindo

Ariana, Sunda., 2017, Manajemen Pendidikan, Yogyakarta, Penerbit Andi

Chaplin, R., 1981, Perkembangan Intelektual Anak, Jakarta, Erlangga

Damsar., 2012, Pengantar Sosiologi Pendidikan, Jakarta, Kencana

Departemen Pendidikan Nasional., 2011, Kamus Besar Bahasa Indonesia, Jakarta, Gramedia Pustaka Utama

Dewantara, W. Agustinus \& Natalis S. Permana., 2019, Penelitian terhadap Minat Menjadi Guru Agama dan Katekis di STKIP Widya Yuwana Madiun, dari Jurnal Pendidikan Agama Katolik

Go, P., 1990, Pendidikan Nilai di Sekolah Katolik, Malang, Dioma

Gulo, W., 2000, Metodologi Penelitian, Jakarta, Grasindo

Hanifah, Nurdinah., 2014, Membedah Anatomi Kurikulum 2013 untuk Membangun Pendidikan yang Lebih Baik, Sumedang, UPT Sumedang Press

Hershberger, Anne K., 2008, Seksualitas Pemberian Allah, Jakarta, Gunung Mulia

Judo, dkk., (2017), Identitas \& Akademik Tidak Saling Menafikkan, Educare, 36.

Kadir, Abdul., 2012, Dasar-Dasar Pendidikan, Jakarta, Prenadamedia Group

Koentjaraningrat., 1959, Antropologi Manusia, Jakarta, Aksara Baru

Komisi Pendidikan., 2008, Dimensi Religius Pendidikan, Jakarta Pusat, KWI

KWI, Majelis Pendidikan Katolik., 2013, Ajaran dan Pedoman Gereja tentang Pendidikan Katolik, Jakarta, Grasindo

Mujahir., 2007, Pendidikan Jasmani Olahraga dan Kesehatan, Bogor, Ghalia Indonesia Printing

Mustafah, J., 2012, Pendidikan Holistik, Jakarta, Kencana Prenada Media Group

Neolaka, Amos \& Amiaila Grace A. Neolaka., 2017, Landasan Pendidikan, Depok, Kencana 
Papo, Y., 1990, Hidup Beriman dalam Lingkup Sekolah,Ende: Nusa Indah

Pujoko, Nurhadi., 2011, Guru Agama Katolik dan Pembinaan Iman Remaja Katolik, dalam Jurnal Pendidikan Agama Katolik

Sagala, Syaiful., 2013, Etika dan Moralitas Pendidikan, Jakarta, Kencana Prenada Media Grup

Santoso, Nurhadi., 2009, "Pendidikan Jasmani di SMA: Antara Harapan danKenyataan”, dalam Jurnal Pendidikan Jasmani Indonesia

SMAK St. Augustinus Kediri., 2018, Buku Pribadi dan Pedoman Siswa. Karya tidak diterbitkan

Sudjana, Nana \& Ibrahim., 2007, Persiapan Penilitian: Prinsip dan Latihan, Jakarta, Kencana Prenada Group

Sujarweni, V. Wiratma., 2014, Metodologi Penelitian,Yogyakarta, Pustaka Baru Press

Sumitro, Albertus., 2005, Diktat Pengantar Pendidikan STKIP Widya Yuwana Madiun, Karya tidak diterbitkan

Suparno, Paul., 2007, Pendidikan Budi Pekerti di Sekolah, Yogyakarta, Kanisius

Supriyadi, Agustinus., 2018, “Orangtua dan Pendidikan Anak dalam Perspektif Gravissimum Educationis bagi Sistem Pendidikan”, dari Jurnal Pendidikan Agama Katolik

Supriyadi, Agustinus., 2016, "Keluarga Kristiani dan Pendidikan Anak dalam Terang Gravissimum Educationis Artikel 3”, dari Jurnal Pendidikan Agama Katolik.

Suratman, dkk., 2010, Ilmu Sosial \& Budaya Dasar, Malang, Intermedia 